\title{
Australia reconsiders claims to Antarctic mineral resources
}

\section{Sydney}

The recently concluded draft Convention on the Regulation of Antarctic Resources is forcing Australia to rethink its claims to large areas of the Antarctic continent. Senator Gareth Evans, the Minister for Foreign Affairs and Trade, invited public debate on the convention when he tabled it in parliament on 23 November.

The draft convention was established at a meeting of 16 nations, including Australia, in Wellington on 2 June after six years of negotiations (see Nature 333, 588; 16 June 1988).

If ratified, the convention will create a Mineral Resources Commission which would review the environmental impact of any proposed activity and decide whether it would be allowed to proceed. If an area is opened for mining, a regulatory committee would issue licences and monitor compliance with conditions imposed.

According to Senator Evans, the convention would establish a legal framework to protect the environment should mineral activity go ahead. But the convention was formulated on the understanding that Antarctica would stay closed to mineral exploitation "unless a specific decision was taken to open it". He stresses that "contrary to some misconceptions, the aim of the negotiation was not to encourage minerals activity".

Environmental groups would prefer that Antarctica remain untouched. Greenpeace would ban all mining activity and declare the continent a world park. In the United Nations, developing nations have condemned the convention, saying that it would lock up the mineral wealth of the Antarctic for a select group of privileged nations. They argue that Antarctica is the common heritage of humanity, and that all nations should participate in its management and share in its natural riches.

In a letter leaked to the press, Australia's Treasurer Paul Keating urged his cabinet colleagues to be cautious in ratifying the convention because it is a threat to Australian sovereignty over the Antarctic territory it has long claimed. As one of the signatories to the 1959 Antarctic Treaty, Australia would automatically become a member of the commission, a position it would have to share with 19 other nations. Any regulatory committee managing territory presently claimed by Australia would comprise ten nations. But under the terms of the convention no territorial claimant would receive any royalties from mining operations.

According to Keating, that concedes Australia's economic claim to 42 per cent of the continent "for virtually nothing" and undermines Australia's claim to sovereignty in the Antarctic.

As Australia's territorial claim is so large, the convention cannot come into effect unless it is ratified by Australia. In the near future Australia is bound to come under political pressure from other partners to the convention who are anxious to press ahead and see it ratified.

Charles Morgan

\section{Historical hut in snow danger}

Sydney

Australian scientists fear that an important historical monument in Antarctica may soon be lost. Lawson's Hut, the oldest scientific base in the Antarctic, was built in 1912 and used by the explorer Sir Douglas Lawson. Wind-driven snow has blasted away the walls of the hut and reduced them to a paper-thin shell.

In 1962, the first expedition to visit the hut since Lawson's party left in 1914 found that the Baltic pine used to construct the building had been worn away to half its original thickness. In 1985 the wood was down to one quarter of its original thickness. Three attempts to reach the hut since then have failed because of harsh weather.

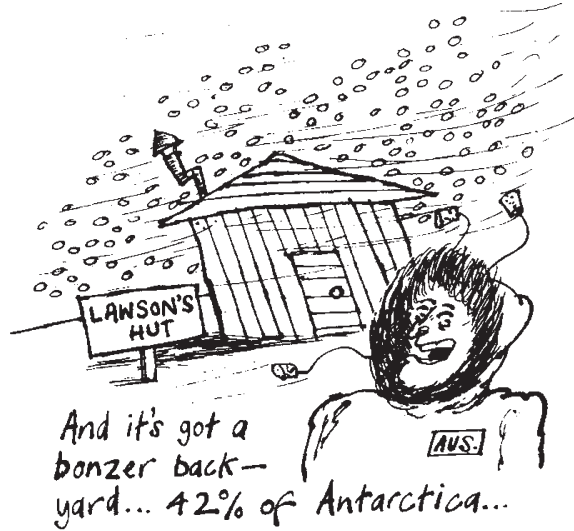

Dr Bill Burch, a member of the 1962 expedition, fears that an attempt to restore the hut in 1985 might have done more harm than good. Ice and snow packed inside the building was dug out, leaving the building in danger of falling apart.

The hut is listed as a protected building in the Antarctic Treaty and included in Australia's National Estate Register. Burch feels that the hut should be dismantled and returned to Australia for display before it is blown away. But the Heritage Commission feels that it is the hut's location that gives it its significance. Australia's Antarctic Division hopes it can come to the rescue with a protective coating for the hut. Charles Morgan
Japan's funding for unusual projects

\section{Tokyo}

QuaNrum electronic devices, pico-second chemistry, and 'plant ecochemicals' feature in the latest three additions to Japan's ERATO (Exploratory Research for Advanced Technology) programme.

The new projects, described at a symposium in Tokyo last week, will run for five years with budgets of $¥ 1,500$ million $¥ 2,000$ million ( $\$ 12-\$ 15$ million) each.

ERATO, set up by the Science and Technology Agency's Research and Development Corporation of Japan in 1981, supports unusual, even eccentric, research that is too risky for industry but which may find applications in the long run. Each project is headed by a senior scientist who supervises a team of 15 to 20 young (under 35 ) researchers drawn from the universities, industry and government institutes. Foreigners are usually included to add an 'international' flavour.

Hiroyuki Sakaki of the Research Center for Advanced Science and Technology at the University of Tokyo heads the 'Quantum Wave' project which will investigate quantum effects in ultramicrosemiconductor devices. When atomicsized structures (layers, boxes, spheres. wires) are constructed in semiconductors. the electrical and optical properties of the semiconductor can be drastically altered because of quantum wave effects that result from the imposition of additional structure at the atomic level. By harnessing and controlling these effects, Sakaki hopes to open up a new field of research.

The 'Micro Photoconversion' project. headed by Hiroshi Masuhara of Kyoto Institute of Technology, will use lasers to drive. measure and control chemical reactions at pico-second timescales in micrometer-sized reaction volumes. Practical applications are foreseen in electronics and new materials.

Junya Mizutanis 'Plant Ecochemical' project carries the most unusual title. Mizutani, who is in the department of agriculture at Hokkaido University, notes that whereas animals can run away when confronted with pests, plants have no option but to remain rooted to the ground and fight a chemical battle.

For example, the leaves of the walnut tree contain a derivative of an aromatic compound (1.4,5-trihydroxynaphthalene) which is converted to the toxin juglone when the leaves fall to the ground. Juglone kills grasses at the base of the tree and also inhibits feeding by some beetles. Mizutani's team will look for ecochemicals" that may have application in agriculture.

David Swinbanks 